\title{
Constraints on School Based Management Compliance of Public Schools Principals
}

\author{
Elysha S. Alvarado, Francis Ann R. Sy, Cerenio Adriatico \\ College of Business and Management, Southern Leyte State University, San Juan, Philippines \\ Email: instructorslsu@gmail.com
}

How to cite this paper: Alvarado, E.S., Sy, F.A.R. and Adriatico, C. (2019) Constraints on School Based Management Compliance of Public Schools Principals. Open Access Library Journal, 6: e5454.

https://doi.org/10.4236/oalib.1105454

Received: May 6, 2019

Accepted: July 2, 2019

Published: July 5, 2019

Copyright $\odot 2019$ by author(s) and Open Access Library Inc.

This work is licensed under the Creative Commons Attribution International License (CC BY 4.0).

http://creativecommons.org/licenses/by/4.0/

(c) (i) Open Access

\begin{abstract}
This study explored how school principals, head teachers, and school heads are coping with the constraints of successfully implementing different programs and activities that are in compliance with the school-based management of RA 9155 as these leaders are oftentimes confronted with voluminous work and encountered a lot of difficulties as they carry out to their administrative and supervisory functions. These competing demands lead to a clear gap between the aspirational and the actual performance in their respective schools. It utilized a descriptive-normative design in conducting the study where 50 respondents were randomly selected and were requested to complete a modified instrument of the Performance Appraisal System for School Administrators (PASSA). Results indicated that school administrators under survey lacked managerial competencies and adequate training in management and leadership in implementing the different programs and projects based on school-based management.
\end{abstract}

\section{Subject Areas}

Education, Sociology

\section{Keywords}

RA 9155, Performance Appraisal System for School Administrators, Training

\section{Introduction}

Republic Act 9155 otherwise known as Governance of Basic Education Act of 2001 or School-Based Management institutes a framework for the governance of primary education, general directions for educational policies and standards, establish authority, accountability and responsibility for achieving higher learning outcomes of essential education services in the country. Following the concept of 
decentralization, this Act empowers all school managers the blanket authority in managing the schools and assumes the multi-faceted tasks such as setting the mission, vision, goals, and objectives of the school; creating an environment conducive to teaching and learning; implementing the school curriculum, school program and improvement plan; offering educational programs, projects and services; innovating modes of instruction; managing personnel, staffing complement, physical and fiscal resources; staff development; establishing community networks; resource generation; and performing other relevant functions as assigned by the District Supervisor.

In recent years, increasing knowledge of the transformative power of school leadership has helped in redefining the role of school managers. [1] said that an administrator has many things to look into in running a school and that one needs the competence to achieve his tasks. Recent literature on headship focused on the role of being an instructional leader [2]. However, management is equally essential [3] mainly in the advent of the school-based management system which is currently implemented across all public elementary and secondary high schools all over the country which drastically redefine the entire landscape of basic education level in the Philippine education system. Some scholars believed that management is a prerequisite to leadership [4]. Control of the day-to-day operation of a school is essential. Leaders might ask such questions: How are we going to put all our resources together to continue to grow, to continue to respond to new needs, to enable the school to be in a place where teaching and learning make more meaningful? Thus, principals should possess different management skills as they are to work with students, teachers, parents, and other stakeholders that comprise the organizational structure of a particular school.

Amid the multitude tasks of a school administrator lies the many constraints that they find the work a difficult one. Most popular clamor is about the stressful nature of their administrative function with many papers' works to do, leaving behind more critical tasks such as curriculum development and instructional supervision. The situation is generally compounded by the passage of Republic Act 9155 otherwise known as Governance of Basic Education Act of 2001 or School-Based Management that mandated school heads and principals in implementing various school programs and projects on their own. Following the concept of decentralization, this Act empowers school managers' full autonomy to run the schools and assume their multi-faceted tasks despite the many constraints. [5] claimed that limitations are boundaries and obstructions that may impede in correctly managing a particular organization. [6], on the other hand, also noted these constraints might limit an organization's performance relative to its objectives. However, [7] [8] believed, successful school leaders, respond productively to challenges and opportunities created by work accountability.

Several studies in the past were conducted in line with different constraints met by school administrators included inadequate funding and physical facilities [9]; process management implementation [10]; curriculum management [11]; 
and management and leadership roles [12]. Some pronounced that their capacity matters while in the study of [13], effective mechanisms were of great help since it cannot be avoided. The quality of being a good administrator matters most to attract students to enroll in a particular school which would bring direct benefit to the school in terms of budget, i.e. the more the number of enrollees, the more significant share of the maintenance and other operating expenses (MOOE) allocation that is intended to finance the recurring expenses incurred every month. Besides, higher enrollment intake also enables the school to obtain additional continuous monetary and in-kind support from parents and other stakeholders within the community.

This study asserted that school administrators continuously experienced constraints in dispensing their respective duties. The theory of constraints developed by Goldratt in the 1980s is a management philosophy that established the fundamental thesis which limits the performance of any system or organization. Common examples of constraints include financial, managerial, administrative, and leadership. [14] [15] [16] further suggested that school principals should possess essential management functions that include the critical elements of the scalar chain (authority and responsibility )which was found to be consistent with the contingency theory [16] [17]. On the contrary, [18] argued that there had been little evidence that School-Based Management has had either a profound or indirect effect on educational outcomes as the primordial aim of our educational system.

In this study, the researchers explored the myriad of constraints experienced by school administrators of public schools in the division of Southern Leyte Province. It utilized the Performance Appraisal System for School Administrators (PASSA), the official evaluation tool issued by the Department of Education that contains the evaluation criteria for instructional supervision; development/implementation of programs; administrative management; and research undertakings that are periodically conducted on a semester basis.

\section{Conceptual Framework}

The study is based on the organizational change theory contending that "human beings tend to resist change even when change represents growth and development [19]. Accordingly, resistance to change is inevitable, and management must be prepared to respond to it. This claim is also anchored on the Chaos Theory by Henri Poincare in management recognized that events indeed are rarely controlled and that systems naturally go to a more complexity, and as they do so, these systems become more volatile or susceptible to cataclysmic events [20]. Hence, managers must expend more energy to maintain that complexity of the arrangements. However, as they continue to spend more power, they seek more structure to maintain stability in the firm. This trend, however, continues until the system splits, combines with another complex system, or falls apart entirely. Karl Max also pointed out an anti-thesis contradicts a thesis to generate a 
new synthesis. It is the trend in what many see as the trend in life, in organizations and the world in general [20] Figure 1 demonstrates the variables used in the study.

\section{Methodology}

In this study, a descriptive-normative survey was used to determine the perceived level of difficulty instructional leaders met in handling their administrative and supervisory functions utilizing the revised questionnaire on the functions of school heads based on the performance appraisal system for school administrators (PASSA) evaluation checklist.

The respondents of the study were the different elementary school heads assigned in the six districts of San Juan, St. Bernard, Anahawan, Hinundayan, Hinunangan and Silago municipalities having a population of 180 school heads. The researchers then used an online sample size calculator in determining the actual number of respondents that were included in the survey by indicating a $10 \%$ margin of error and approximating a 50\% response distribution. Based on the calculation, the recommended sample size was 50 . The utilization of the modified PASSA questionnaires had a prior approval from the Education Program Specialist who has the authority of implementing and/or conducting researches catered to programs and services of basic education. In addition, follow-up interviews were also conducted to ascertain the validity of the written responses. Meanwhile, the researchers also sought the final approval of the Division Superintendent before fielding the survey instrument to 50 randomly selected respondents from the six municipalities covered in the study. Data were assessed using the weighted mean and standard deviation. In completing the questionnaire, the respondents were asked to indicate the difficulty level from a 4-point rating scale consisting of: 1 = low level of difficulty; 2 = average level of difficulty; 3 = high level of difficulty; and 4 = very high level of difficulty. Using the weighted mean, the following descriptive scales for difficulty were established: $1.0-1.75=$ low; $1.76-2.50=$ average; $2.51-3.25=$ high; and $3.26-4.0=$ very high.

In addition, the deviation from the average (sum of absolute difference divided by the number of responses), was calculated to give an accurate picture of the responses. The deviation is commonly used to describe the extent to which a collection of data (responses) values is dispersed around its mean (average). A small deviation means the values tend to be close to their average. On the reverse, a large deviation means that the values are widely scattered on their averages. In this study, a small deviation reflects a higher or greater consensus about the statement while a high deviation denotes poor or no consensus at all with regard to a certain statement. The scoring used is as follows: Scoring $<0.75=$ high or greater consensus, $>0.75=$ poor or no consensus.

The profile of the respondents of the study according to gender distribution and current position are presented in Table 1. 


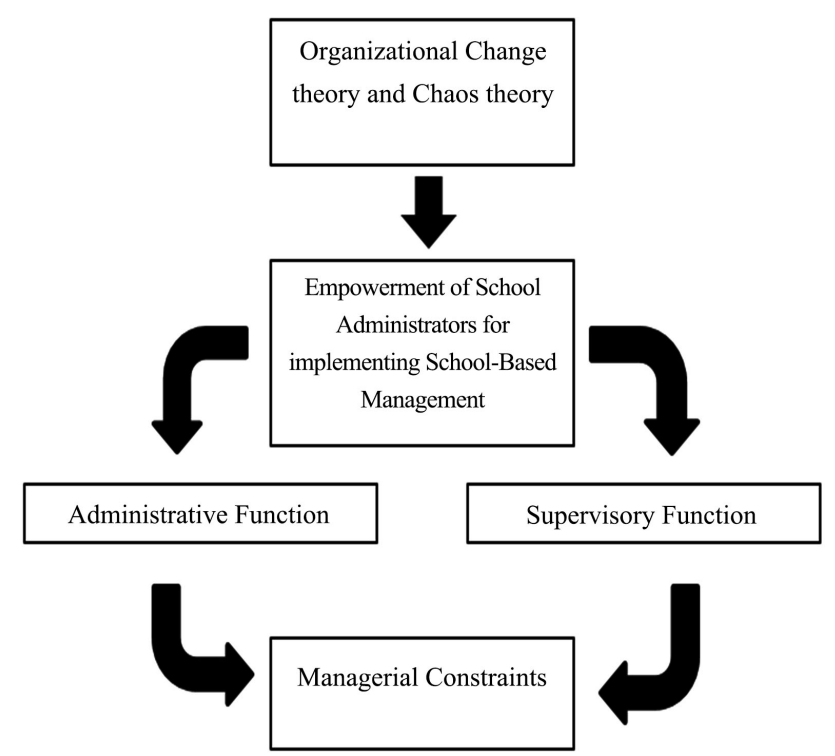

Figure 1. The conceptual framework of the study.

Table 1. Gender distribution and current position of the respondents.

\begin{tabular}{cccc}
\hline & \multicolumn{2}{c}{ Gender } & Total \\
\cline { 2 - 3 } Position & Male & Female & \\
\cline { 2 - 4 } & Frequency & Frequency & Frequency \\
\hline Full-pledged Principals & 8 & 21 & 29 \\
Head Teachers & 3 & 11 & 14 \\
School in-Charge & 1 & 6 & 7 \\
Total & 12 & 38 & 50 \\
Percentage & 24 & 76 & 100 \\
\hline
\end{tabular}

\section{Results and Discussion}

\subsection{Administrative Functions of Respondents}

Sample characteristics described in Table 2 revealed that the mean age of 39 years old and the mean years working in their current position show the maturity level of the school heads and have subsequently accumulated considerable experience of managing their respective schools. These school heads have supervised an average of 10 teachers per school. The Philippines public school system is often characterized by smaller elementary schools scattered across all rural barangays of the country which are categorized as financially challenged communities.

In rating the administrative functions of school heads, all the respondents perceived a high level of difficulty in managing human resources, managing physical facilities, maintaining data management, handling conflict, and establishing community network. 
Table 2. Individual characteristics and administrative functions variables.

\begin{tabular}{|c|c|c|c|c|}
\hline Variables & Measures & Mean & $\begin{array}{l}\text { Standard } \\
\text { deviation }\end{array}$ & Descriptors \\
\hline \multicolumn{5}{|l|}{$\begin{array}{l}\text { Individual } \\
\text { characteristics }\end{array}$} \\
\hline Age & & 38.80 & 7.667 & \\
\hline $\begin{array}{l}\text { Years serving as school } \\
\text { head }\end{array}$ & $\begin{array}{l}1=1-10 \text { years } \\
2=11-20 \text { years }\end{array}$ & 7.5 & 4.683 & \\
\hline Teachers supervised & $\begin{array}{l}1=1-10 \text { teachers, } \\
2=11-20 \text { teachers }\end{array}$ & 10.78 & 1.855 & \\
\hline Gender & $1=$ male, $2=$ female & 1.60 & 0.495 & \\
\hline $\begin{array}{l}\text { Administrative } \\
\text { functions }\end{array}$ & $\begin{array}{l}\text { 4-point scale from } \\
\text { "1 = low level of difficulty", } \\
2=\text { average level of difficulty, } \\
3 \text { = high level of difficulty to } \\
4 \text { = very high level of difficulty" }\end{array}$ & & & \\
\hline Human resource & & 2.76 & 1.098 & High \\
\hline Physical facilities & & 2.70 & 0.974 & High \\
\hline Data management & & 2.70 & 0.909 & High \\
\hline Conflict management & & 2.76 & 0.981 & High \\
\hline Linkage management & & 2.76 & 1.041 & High \\
\hline
\end{tabular}

\section{Managing human resources}

The respondents noted the mismatch of teachers assigned in their schools such that secondary school teachers were hired to teach in grade school subjects. They further mentioned tardiness, absenteeism, lack of commitment in seriously doing the job and attitude of teachers were the many constraints that have to be addressed by the school heads who are responsible for managing the day-to-day operations of instruction delivery and performance of students. Thus, the challenges faced by the principals are becoming multifold, often, remain unnoticed in a fluid environment that is subject to rapid changes due to internal and external factors [21] [22] [23] [24]. Also, the hiring of teachers is done at the provincial level instead of at the local level. The principal has no hand during the recruitment and hiring process of teachers in the Department of Education.

Managing physical facilities

Proper maintenance of the school physical facilities such as buildings, parks, playgrounds, hand washing facilities, dental trough, library, office and laboratory equipment, and audiovisual materials is one the core functions addressed by the school administrators. In many elementary schools in rural areas, there is an apparent lack of qualified personnel assigned to handle the properties of the schools. Besides, facility management is also considered an interdisciplinary field devoted to the coordination of space, infrastructure, people, and organization. Facility management is to coordinate space, infrastructure often associated with the administration of office blocks, arenas, and schools. In a 2009 Global Job Task Analysis, the International Facility Management Association (IFMA) iden- 
tified core competencies of facility management such as communication, emergency preparedness, business continuity, environmental stewardship and sustainability, finance and business, leadership and strategy, operations and maintenance, project management, real state and property management, and technology. School administrators must ensure that these activities be well taken since the more equip the school is, the more it will be on edge over others. Whenever accreditation comes, the school is ready and also become globally competitive. Besides, there is a high possibility that enrolment will increase if this is the case.

Data management

The required implementation of the education management information system (EMIS) is perceived as a significant constraint by the school administrators since they lacked the rudiments in using the system. Moreover, the administrators are also required to maintain adequate documentation needed in school-based management Philippines Accreditation System of Basic Education (SBM-PASBE) and the school monitoring and evaluation adjustment (SMEA) which generally complicate in their daily chores. Although technology is a boost in this data-driven environment, the administrators felt they were incapable of successfully managing data in their respective school.

Conflict management

Resolving conflict is the practice of being able to identify and handle disputes sensibly, reasonably and efficiently at a lesser cost. Many school heads thought conflict management as one demanding task to comply. Any organization, no matter how small are always comprise of people with diverse backgrounds, cultures, feelings, attributes, and perspectives to mention a few. The perceived difficulty felt by the administrators were found consistent with the findings that [23] conflict is inevitable across the organizational hierarchy in both government and private organizations.

Linkage management

Establishing a network in the community and other stakeholders of the primary schools are becoming popular in the country; nevertheless, most of the administrators under survey perceived this task a bit daunting. In practice, school principals are rotated to another school every three years, or even they have strengthened the collaboration. With minimal funding provided by the central office for the maintenance and other operating expenses, school principals have to secure additional funding coming from the community, local government units, and potential donors. Maintaining strategic linkages with the communities would generate other benefits to the school [24]. It senses the shared identity of community development as social capital. The more stakeholders involved in school activities, the better the school will become. Thus, the school and community should work hand in hand in reviewing their vision and goals and identify the opportunities concerning the school-community linkage for improvement. Spending quality time with the parents and the community is a must for every school leader (Table 2). 


\subsection{Disaggregating Perceptions of the Respondents}

To determine a deeper understanding of the responses, the data were further disaggregated by sex, and the results are presented in Table 3. In this table, both sexes perceived a high level of difficulty in all the areas of human resources, physical facilities, data management, and conflict handling and linkage management. On average, the weighted mean scores of male respondents in the five areas of the administrative functions are 3.02, higher than the mean scores obtained by female participants, which is only 2.55 .

Table 3. Perceptions based on disaggregated data by gender.

\begin{tabular}{|c|c|c|c|c|}
\hline Variables & Measures & Mean & $\begin{array}{l}\text { Standard } \\
\text { deviation }\end{array}$ & Descriptors \\
\hline \multicolumn{5}{|l|}{ Male respondents } \\
\hline Age & & 40.45 & 8.262 & \\
\hline $\begin{array}{l}\text { Years serving as school } \\
\text { head }\end{array}$ & $\begin{array}{l}1=1-10 \text { years } \\
2=11-20 \text { years }\end{array}$ & 6.067 & 3.084 & \\
\hline Teachers supervised & $\begin{array}{l}1=1-10 \text { teachers } \\
2=11-20 \text { teachers }\end{array}$ & 11.60 & 1.875 & \\
\hline $\begin{array}{l}\text { Administrative } \\
\text { functions }\end{array}$ & $\begin{array}{l}\text { 4-point scale from } \\
\text { "1 = low level of difficulty", } \\
2 \text { = average level of difficulty, } \\
3 \text { = high level of difficulty to } \\
4 \text { = very high level of difficulty" }\end{array}$ & & & \\
\hline Human resource & & 3.05 & 0.999 & High \\
\hline Physical facilities & & 3.00 & 0.973 & High \\
\hline Data management & & 2.85 & 0.671 & High \\
\hline Conflict management & & 3.15 & 0.933 & High \\
\hline Linkage management & & 3.05 & 0.826 & High \\
\hline \multicolumn{5}{|l|}{ Female respondents } \\
\hline Age & & 37.70 & 7.173 & \\
\hline $\begin{array}{l}\text { Years serving as school } \\
\text { head }\end{array}$ & $\begin{array}{l}1=1-10 \text { years } \\
2=11-20 \text { years }\end{array}$ & 6.067 & 3.084 & \\
\hline Teachers supervised & $\begin{array}{l}1=1-10 \text { teachers } \\
2=11-20 \text { teachers }\end{array}$ & 10.233 & 1.6543 & \\
\hline $\begin{array}{l}\text { Administrative } \\
\text { functions }\end{array}$ & $\begin{array}{l}\text { 4-point scale from } \\
\text { "1 = low level of difficulty", } \\
2 \text { = average level of difficulty, } \\
3 \text { = high level of difficulty to } \\
4 \text { = very high level of difficulty" }\end{array}$ & & & \\
\hline Human resource & & 2.57 & 1.135 & High \\
\hline Physical facilities & & 2.50 & 0.937 & High \\
\hline Data management & & 2.60 & 1.037 & High \\
\hline Conflict management & & 2.50 & 0.937 & High \\
\hline Linkage management & & 2.57 & 1.135 & High \\
\hline
\end{tabular}


Constraints are natural phenomena in any school that provide challenges and opportunities to instructional leaders in their respective stations. The disaggregated results showed males were generally more resilient in performing their functions compared to their female counterparts. Given the limited resources, school heads have to establish linkages with stakeholders (community, alumni, local government units) for additional funding and other forms of support.

Overall, the results further suggested that school principals, head teachers, and school heads should be provided with intensive training on basic management program since they are both acting as managers and leaders. It is further supported the said activities [24] [25] [26] indicate an excellent management foundation, a prerequisite to better leadership.

The high level of difficulty felt by the school administrators on the variables of administrative functions indicated their apparent lack of managerial capabilities.

\section{Conclusions}

Organizational change theory requires school managers should have a broad understanding of how systems and organizations work in carrying out their respective duties and responsibilities effectively. In this particular study, it has been revealed that most of our instructional leaders working in the Division of Southern Leyte had a high level of difficulty in managing the areas of human resource, physical facility management, data handling and management, conflict resolution and management, establishing linkage including the performing instructional, supervisory functions. The role of the school administrators had continuously evolved from managerial to leadership functions. Currently, these instructional leaders are perceived as the leader bringing change and transformation in their respective organizations. Due to the above-identified shortcomings, the study concluded the actual performance of principals, school heads, and head teachers were way below the expected standards and criteria of school-based management frame of reference. To mitigate the current problems, the researchers recommend the following interventions for implementation by the Department of Education-Southern Leyte Division:

1) Conduct comprehensive training on managing the school-based management system.

2) Require all school managers to attend related training on adequate supervision, curriculum development, and accomplishing of the monthly and quarterly instructional, supervisory plan.

3) Periodically monitor the performances to determine that the actual accomplishments fully comply with the agreed management standards.

4) Related research may be undertaken to monitor enhanced managerial competencies of the school managers.

Since the data collected are relatively small scale and limited, further research is encouraged to explore consistencies of the results relevant to the current findings. 


\section{Conflicts of Interest}

The authors declare no conflicts of interest regarding the publication of this paper.

\section{References}

[1] Boyd, D., Grossman, P., Ing, M., Lankford, H., Loeb, S. and Wyckoff, J. (2011) The Influence of School Administrators on Teacher Retention Decisions. American Educational Research Journal, 48, 303-333. https://doi.org/10.3102/0002831210380788

[2] Glickman, C.D., Gordon, S.P. and Ross-Gordon, J.M. (2001) Supervision and Instructional Leadership: A Developmental Approach. Allyn \& Bacon/Longman Publishing, Needham.

[3] Lunenburg, F.C. (2010) The Management Function of Principals. National Forum of Educational Administration \& Supervision Journal, 27.

[4] Lunenburg, F.C. (2010) The Principal and the School: What Do Principals Do? National Forum of Educational Administration \& Supervision Journal, 27.

[5] Hawkins, P. (2003) The Open Economy and Its Financial Constraints.

[6] Goldratt, E.M. and Cox, J. (2016) The Goal: A Process of Ongoing Improvement. Routledge, Abingdon-on-Thames. https://doi.org/10.4324/9781315270456

[7] Goldratt, E.M. (1990) Essays on the Theory of Constraints. North River Press, Great Barrington.

[8] Southworth, G. (2002) Instructional Leadership in Schools: Reflections and Empirical Evidence. School Leadership \& Management, 22, 73-91.

https://doi.org/10.1080/13632430220143042

[9] Mulford, B. (2003) School Leaders: Challenging Roles and Impact on School and Teacher Effectiveness. Dokumentas, parengtas EBPO Lyderystès tobulinimo mokykloje projektui.

[10] Hale, E.L. and Moorman, H.N. (2003) Preparing School Principals: A National Perspective on Policy and Program Innovations. Institute for Educational Leadership, Washington DC.

[11] Adisomelle, A.O. (2015) Constraints to Management of School Curriculum: A Study of Public Primary Schools in Loiyangalani District of Marsabit County, Kenya. Doctoral Dissertation, School of Education, Kenyatta University, Kahawa.

[12] Tobin, J. (2014) Management and Leadership Issues for School Building Leaders. International Journal of Educational Leadership Preparation, 9.

[13] Murphy, J., Hallinger, P., Peterson, K.D. and Lotto, L.S. (1987) The Administrative Control of Principals in Effective School Districts. Journal of Educational Administration, 25, 161-192. https://doi.org/10.1108/eb009930

[14] Corcoran, A., Casserly, M., Price-Baugh, R., Walston, D., Hall, R. and Simon, C. (2013) Rethinking Leadership: The Changing Role of Principal Supervisors. Council of Great City Schools, Washington DC.

[15] Bautista, M.C.R.B., Bernardo, A.B. and Ocampo, D. (2009) When Reforms Don't Transform: Reflections on Institutional Reforms in the Department of Education.

[16] Cheng, Y.C. (1994) Principal's Leadership as a Critical Factor for School Performance: Evidence from Multi-Levels of Primary Schools. School Effectiveness and School Improvement, 5, 299-317. https://doi.org/10.1080/0924345940050306 
[17] Lewis, J. and Caldwell, B.J. (2005) Evidence-Based Leadership. The Educational Forum, 69, 182-191. https://doi.org/10.1080/00131720508984682

[18] Fine, M. (1986) Why Urban Adolescents Drop into and out of Public High School. Teachers College Record, 87, 393-409.

[19] Pool, R. (1989) Chaos Theory: How Big an Advance? Science, 245, 26. https://doi.org/10.1126/science.2740911

[20] Blackler, F. (1993) Knowledge and the Theory of Organizations: Organizations as Activity Systems and the Reframing of Management. Journal of Management Studies, 30, 863-884. https://doi.org/10.1111/j.1467-6486.1993.tb00470.x

[21] Molina, B.S., Smith, B.H. and Pelham Jr., W.E. (2005) Development of a School-Wide Behavior Program in a Public Middle School: An Illustration of Deployment-Focused Intervention Development, Stage 1. Journal of Attention Disorders, 9, 333-342. https://doi.org/10.1177/1087054705279301

[22] Kruse, S.D. and Louis, K.S. (2008) Building Strong School Cultures: A Guide to Leading Change. Corwin Press, Thousand Oaks.

[23] McKinney, B.K. (2011) Withstanding the Pressure of the Profession. Journal for Nurses in Professional Development, 27, 69-73. https://doi.org/10.1097/NND.0b013e31820eee6a

[24] Kilpatrick, S.I., Johns, S.M., Mulford, W.R. and Prescott, E.N. (2002) More than an Education: Leadership for Rural School-Community Partnerships.

[25] Lunenburg, F.C. and Irby, B.J. (2005) The Principalship: Vision to Action. Thomson Wadsworth, Stamford.

[26] Smith, D.M. and Holdaway, E.A. (1995) Constraints on the Effectiveness of Schools and Their Principals. International Journal of Educational Management, 9, 31-39. https://doi.org/10.1108/09513549510095103 